\section{Samtid og museer i Norge}

Samarbeidet mellom en gruppe museer og Sekretariatet for samtidsdokumentasjon har kommet over i en ny fase. Våren 2000 går ni museer $\mathrm{i}$ gang med mindre prosjekter som alle rar opp inceressante sider ved norsk samfunns- og kulturliv i dag.

Erfaringene fra 1999 ble oppsummert på er seminar ved Norsk Folkemuseum 22. november. Deltakerne ga uttrykk for at samarbeidet så langt har vært nyttig, og de onsker å utvikle det videre. Det skal skje ved at hvert av museene gjennomforer en mindre, klart avgrenset samtidsundersøkelse. Errer planen skal arbeidet være avslutter $i$ løper av høsten 2000. Samarbeidet er forøkt utformet ut fra hvert museums spesielle behov og ressurser. Sekretariatet vil gi hver deltaker best mulig oppfølging og størte $\mathrm{i}$ arbeidet.

Det er spenstige prosjekter museene nå gir seg $\mathrm{i}$ kast med! Loformuseer vil undersøke hvordan symboler på nordnorsk identitet omdannes til suvenirer myntet på et voksende turistmarked. Museet mener det er viktig å gi en beskrivelse av hvilke symboler som tilskrives lokalsamfunnene $\mathrm{i}$ dag og videre inn $\mathrm{i}$ framtida. Norsk Oljemuseum onsker å bli et møtested for de ulike akrørene $\mathrm{i}$ oljevirksomheten og være en kanal for deres historier. Dykkere fra Nordsjøen vil bli intervjuet, og det planlegges et feltarbeid om bord på en installasjon. Jærmuseet vil sammenlikne driftsformene på to gårdsbruk og vise hvilke faktorer som ligger bak valget. Valdres Folkemuseum drar til fjells! Hvilke interesser knytter seg til seterlivet $\mathrm{i}$ dag? Har en slik gammel og tradisjonsrik næringsvei noen framtid? Utvalgte brukere, forst og fremst kvinner, vil bli intervjuet om sitt forhold til setra. Ryfylkemuseet fortsetter et samarbeid de har innledet med bosniske flyktninger og vil gå nærmere inn på den identitersproblematikken disse menneskene arbeider med. Maihaugen fortsetter sin dokumentasjon av hjem og boliger. Vestnorsk Industristadmuseum og De Heibergske
Samlinger prøver ut opplegg der barn dokumenterer og formidler sin egen situasjon ved hjelp av blant annet fotografier. Perspektivet museum vil følge prosessen med å etablere et ungdommens hus i Tromsø i 2000 . Undersøkelsen er del av et større prosjekt som rar opp ungdommer, møreplasser og musikk fra 1950-tallet til i dag. Norsk Folkemuseum tar for seg den nye kafékulturen representert ved kaffebarene som mer og mer setter sitt preg på bybildet i Oslo og andre srorre byer. Hvem er brukerne og hvordan fungerer disse møreplassene? Hvorfor får vår velkjente nasjonaldrikk så mye oppmerksomhet?

Erfaringer og resultater fra prosjektene vil bli lagt fram på ro felles seminarer våren og høsten 2000 . Det forste vil dreie seg om feltarbeidet, det andre vil ta for seg bearbeiding, registrering og arkivering ved det enkelte museum. Dokumentasjonsarbeidet vil bli oppfattet som en aktiv handling, gjennom utvalg, tolkning og presentasjon tilskrives det som blir undersøkt bestemte verdier. Sammen vil delrakerne diskurere ulike valg, mulige løsninger og etiske sporsmål. En mindre, felles metodedel vil dreie seg om hvordan vi velger å gjøre beskrivelser. Resultater fra prosjektene vil bli brukt i formidling ved hvert enkelt museum og $i$ en felles presentasjon med rekst og bilder på Internetr. Til høsten vil nye museer få tilbud om å være med på liknende opplegg.

Svein Gynnild,

Sekretariatet for samtidsdokumentasjon

\section{Lene Floris och Annette Vasström: På museum \\ - mellem oplevelse og oplysning. \\ Roskilde Universiretsforlag. Roskilde 1999. \\ ISBN 87-7867-033-0.}

P’å museum av Lene Floris och Annette Vasström är ett mycket välkommet tillskott till de ännu ganska fåtaliga bidragen till den museologiskt inriktade litteraturen i Norden. Boken ingår i en serie under- 